تأثير سه تنظيم كننده رشد بر عملكرد دانه ارقام گندم در رزيمهاى متفاوت رطوبتى

\author{
محمد اسماعيل صداقت' و يحيى امامץ*

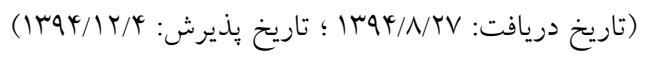

جكيده

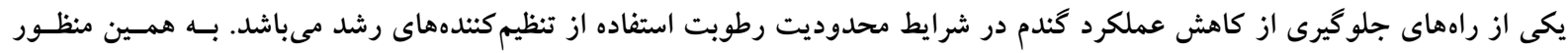

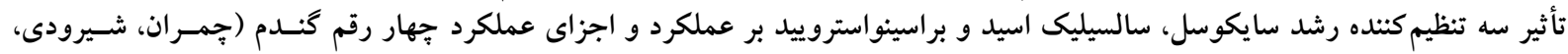

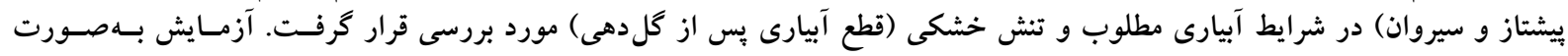

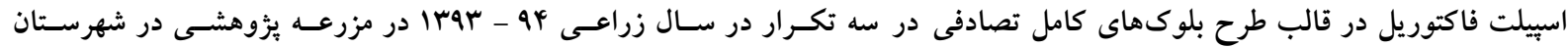

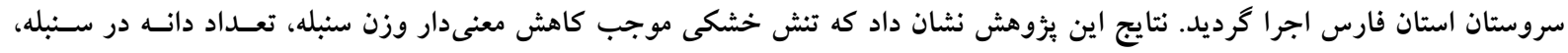

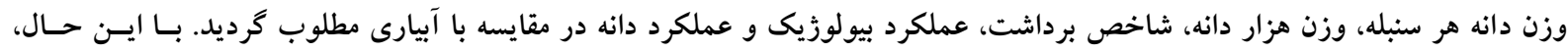

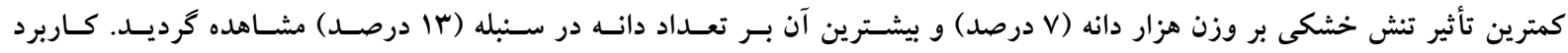

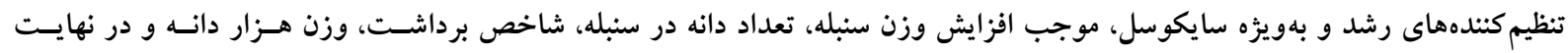

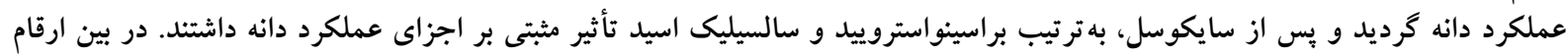

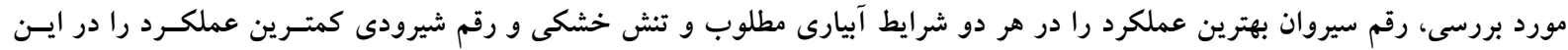

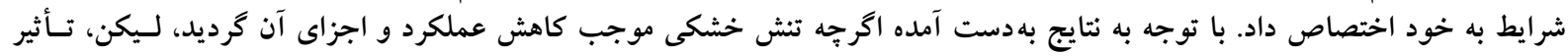

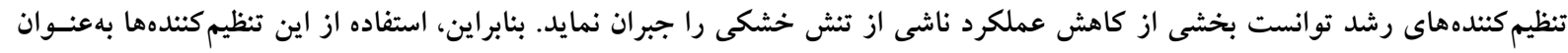

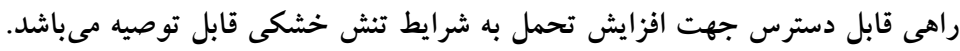

وازههاى كليدى: براسينواستروييد، سالسيليك اسيد، سايكوسل، شاخص برداشت، عملكرد بيولوزيك

ا و r. بهترتيب دانشجوى كارشناسى ارشد و استاد، كروه زراعت و اصلاح نباتات، دانشكده كشاورزى، دانشخاه شيراز

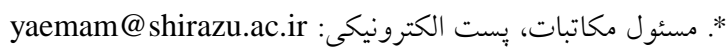


مىشود. سايكوسل از گـروه تركيبـات آمونيـومى بـوده و از

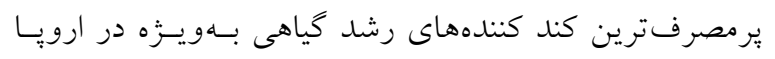

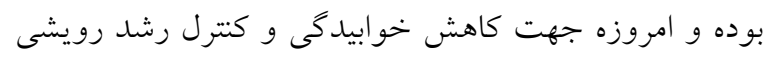
كياهان زراعى بهويزه غـلات كـاربرد فروانسى دارد (1 و و 9).

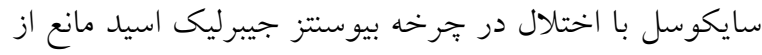

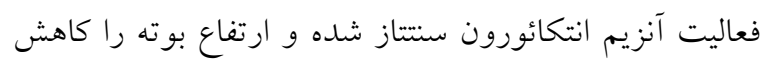

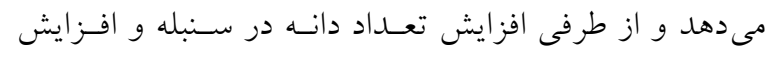

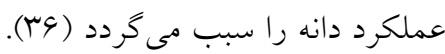
ساليسيليك اسيد نيز بهعنوان يك تنظيمكنده رشد ديخـر

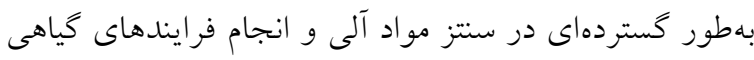

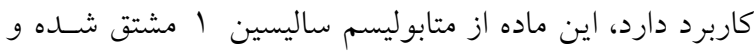

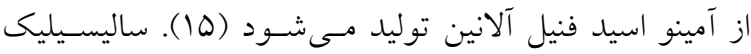

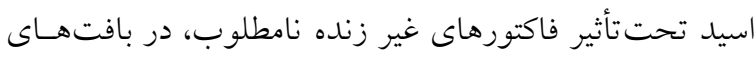

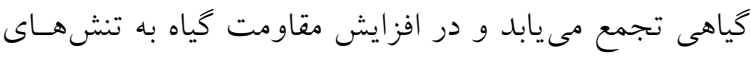

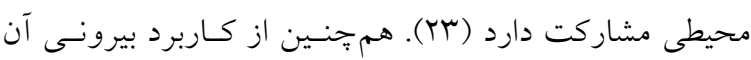

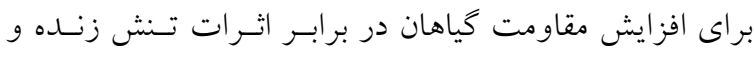

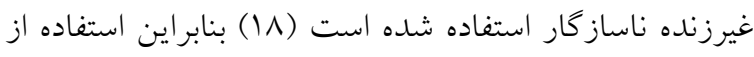

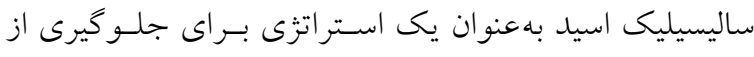

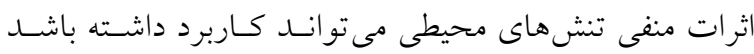

علاوه بر اين، ساليسليكى اسـيد بـهنــوان يـك مولكـول

ييامرسان مهم در پِاسخهاى كياه به تنشهاى متعدد زيستى و

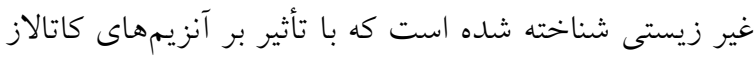

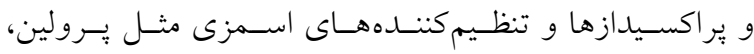

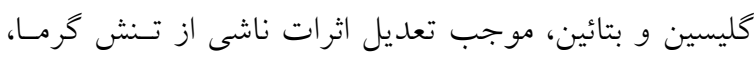

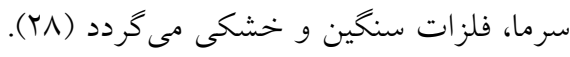
دسته ديخرى از تنظيم كندههاى رشد براسينواستروييدها مى باشند. براسينواستروئيدها براى اولـين بـار در سـال $19 V 9$

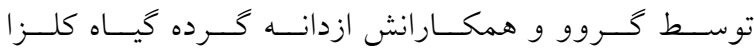
(Brassica napus) كروه جديد از تنظيم كنندههاى رشد بــا اثـرات زيسـتى قابـل

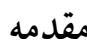
كنــم (Triticum aestivum L.) يكسى از عمــدهتـرين

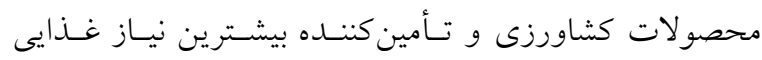

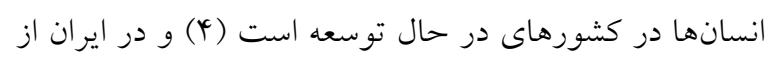
نظر توليد و سطح زير كشت مهمترين محصول زراعى بـودهـ

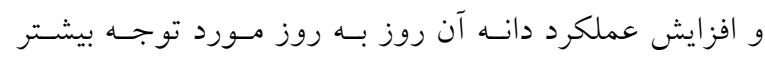

يزو هشخران بوده است (11)

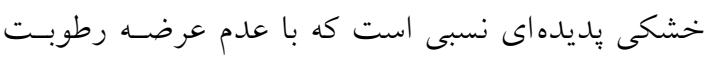

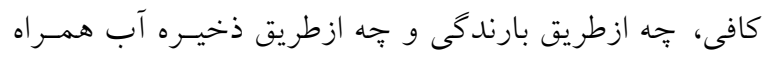

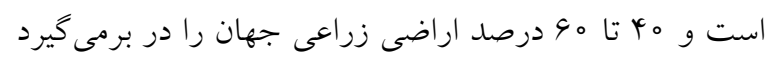

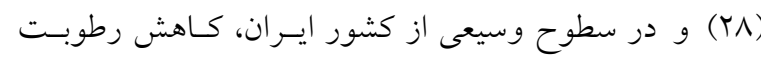

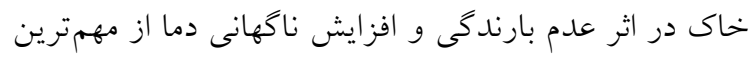
عوامل كاهشدهنده رشد و عملكرد كَندم بـهـــمار مسىرود.

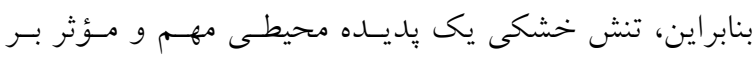

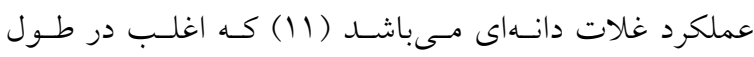
مرحله ير شدن دانه در كندم رخ مسى دهـــ و باعـث كـاهش

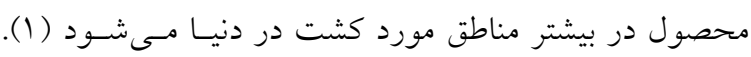

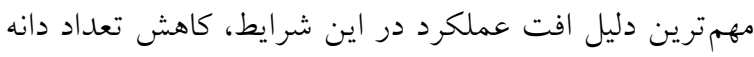
بهعلت خشك شدن دانههاى گرده گزارش شده است (Yo ). بـهنظــر مسىرســـ در شــر ايط كمبـود آب، اسـتفاده از

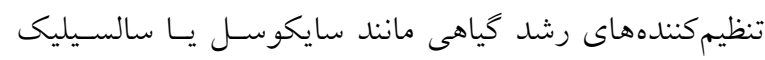

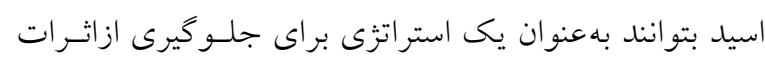
منفى تنش خشكى بهكار رود. در اين راستا بررسىهاى انجام

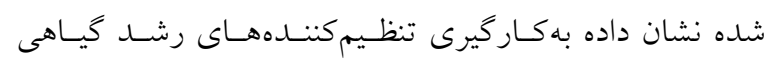

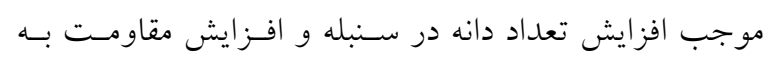

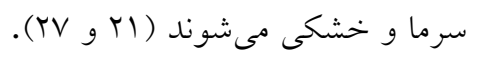

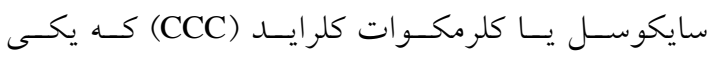

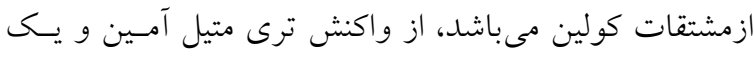

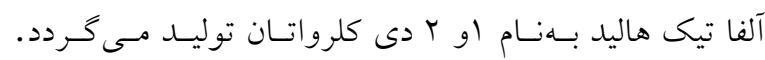

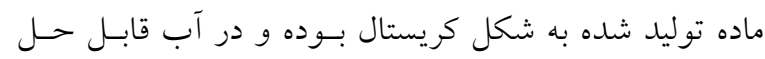

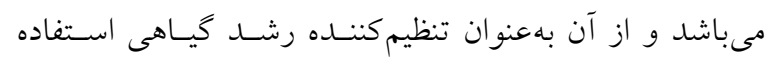


براسينواستروييد (مصرف و عدم مصرف) و ارقـام گنـدم بـا

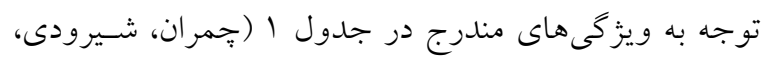

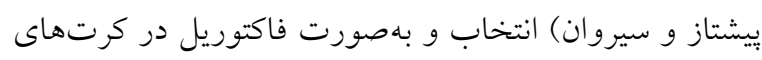

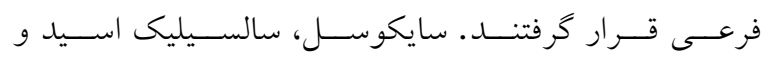

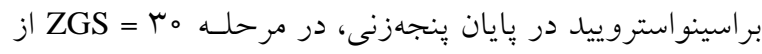

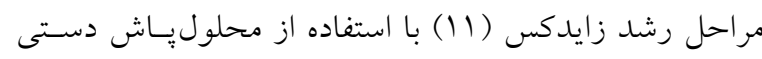
دقيق و با فشار ثابت مَ بار انجام يذيرفت.

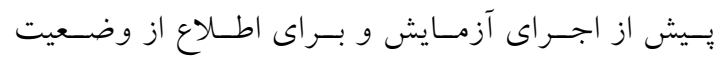

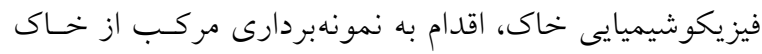

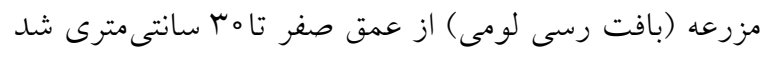

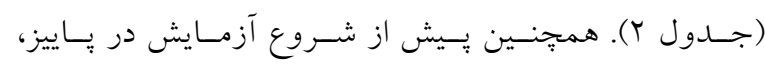

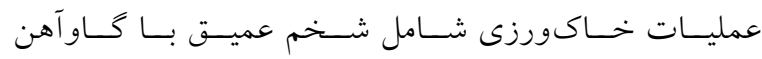
بركرداندار، دو بار ديسـك عمـود بــرهم و لـولر بـود. قبـل ازكاشت تمام كود فسفر مورد نياز بـهـهـورت سويرفسـفات

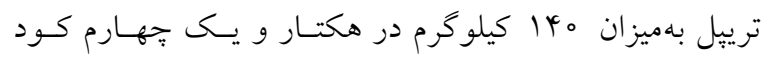

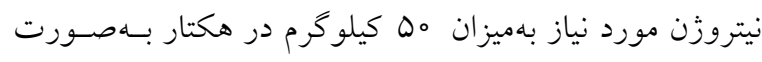

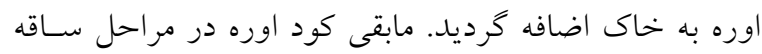
رفتن و قبل از كل دهى هر كدام بهميزان VQ كيلو گرم در هكتار

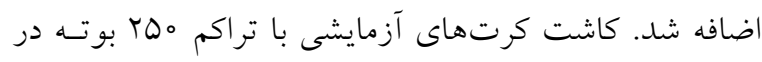

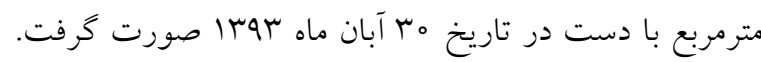

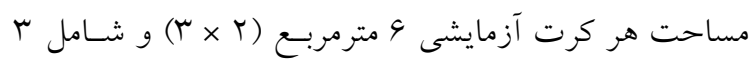

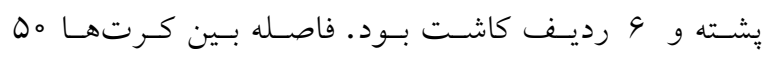

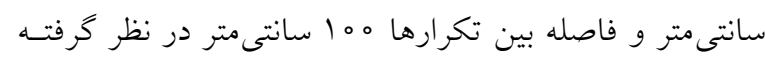

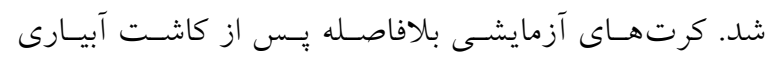

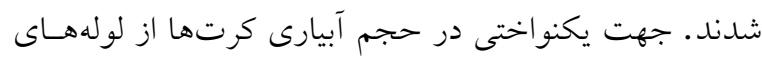

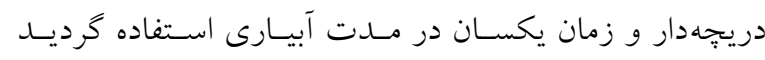
كنترل علفهاى هرز نيز بهصورت وجسين دستى در طـول.

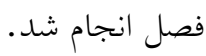

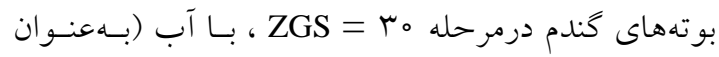
شاهد)، تنظيم كنندهاى سايكوسل (غلظت ب گــرم در ليتـر)،

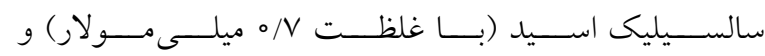

توجه معرفى شـدند (TO). از آن زمـان تـاكنون از وه نـوع

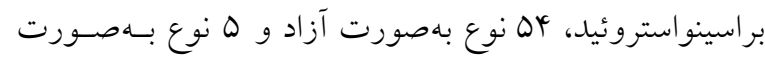

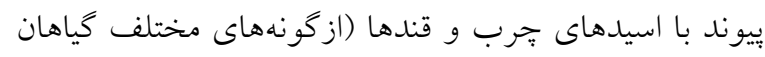

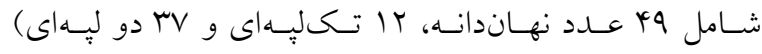

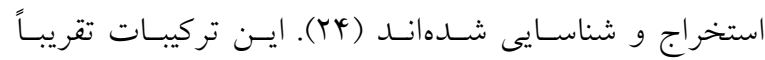

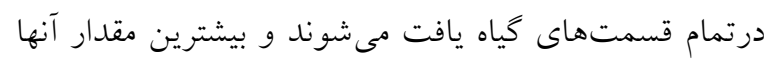

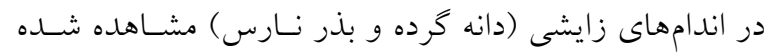
است (ب).

با وجود دسـتاوردهاى مهـم در جهـت درك ياسـخهـاى

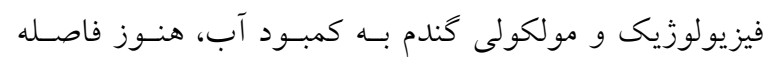

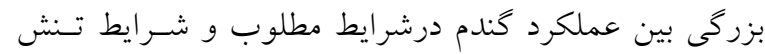

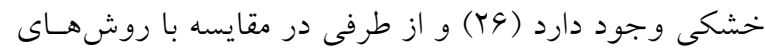
اصلاحى كه اغلب بلند مدت و هزينهبر مى باشند، استفاده از تنظيم كنندهاى رشد آسانتر و ارزانتر است (r) ـ به هم- هـين منظور بُزوهش حاضر براى بررسى تأثير سه تنظيم كننده رشد

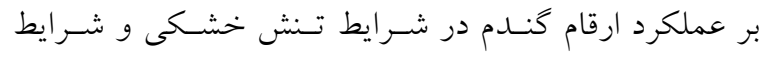
مطلوب انجام شده است.

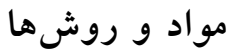

بهمنظور بررسى تأثير تنظيم كنندهاى رشد و تنش خشكى بر

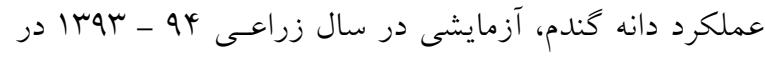

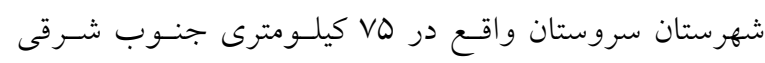

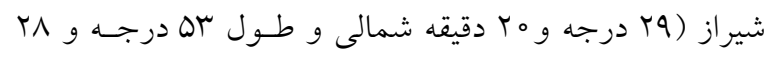

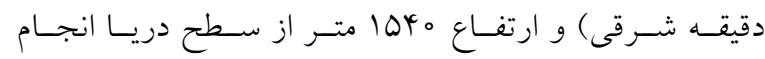
يذّيرفت. اين آزمايش بهصورت اسيليت فاكتوريـل در قالـب

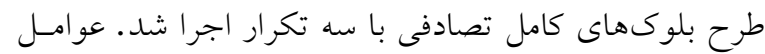

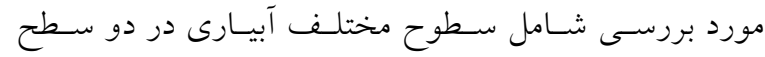
شامل آبيارى مطلوب و قطع آبيارى يس از گل يدهى بهعنـوان

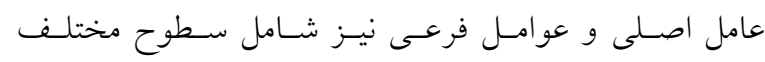

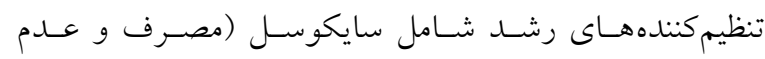

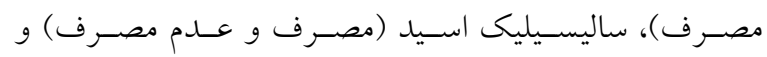


نشريه توليد و فرآورى محصولات زراعى و باغى / سال ششم / شماره بيست و يكم / باييز ههrا

ב

جدول ا. برخى ويزگگىهاى زراعى ارقام گندم مورد استفاده ( آس)

\begin{tabular}{|c|c|c|c|c|}
\hline اقليم مورد كشت & واكنش به تنشهاى محيطى & مقاومت به ريزش & تاريخ رسيدن & 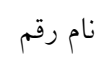 \\
\hline معتدل & نيمهمتحمل & نيمه حساس & زودرس & جمران \\
\hline كرم تا معتدل & متحمل به خشكى & نيمهمقاوم & زودرس & ل ا شيرودى \\
\hline معتدل & متحمل به خشكى & متحمل & نسبتاً زودرس & ي بيشتاز \\
\hline معتدل & متحمل به كرما و خشكى & 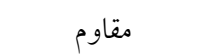 & متوسطرس & سيروان \\
\hline
\end{tabular}

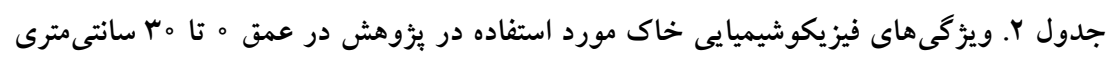

\begin{tabular}{|c|c|c|c|c|c|c|c|}
\hline (درصد) & (درصد) & شن & نيتروزن كل & كربن آلى (درصد) & (ميلى گرم بر كيلو رُم) & 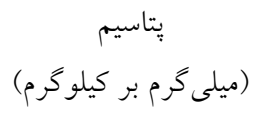 & اسيديته \\
\hline ro & py & 19 & $\circ / 0 \wedge$ & $0 / 9 V$ & $10 / 0$ & TMG & $V / 9$ \\
\hline
\end{tabular}

براسينواستروييد (از براسيفن محصول شـركت آريـا تـرامس نتايج و بحث

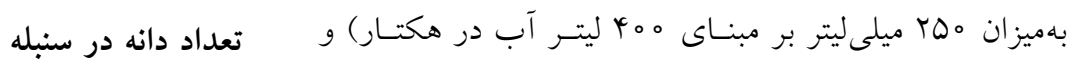
بهصورت كاربرد شاخسارهاى تيمار شدند. محلول سايكوسل در اين بزوهش تنش خشكى موجب كاهش معنىدار تعداد دانه

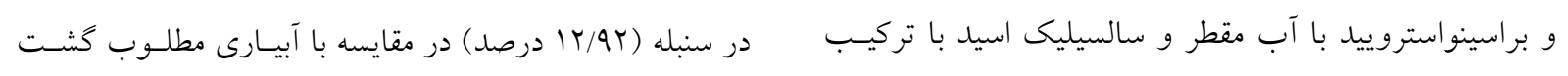

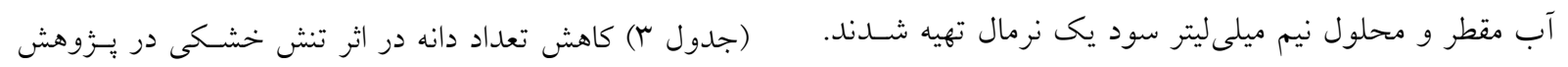

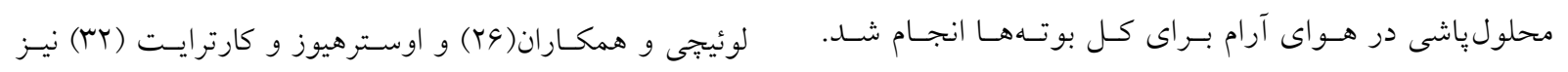

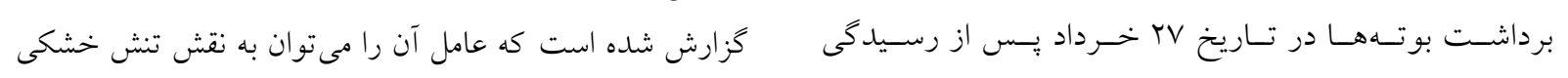

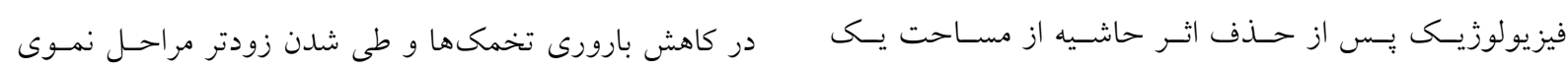

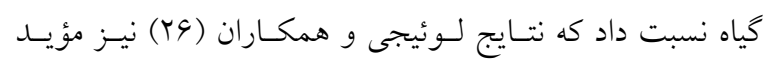

$$
\text { همين موضوع مىباشد. }
$$

در بين تنظيم كنندههاى رشد تفاوت معنى دارى در تعداد دانه در هر سنبله مشاهده نظخرديد. هرجند هر سه تنظيمكنــده رشــ مورد استفاده موجب افزايش تعداد دانه در هر سنبله در مقايسه

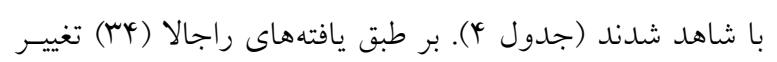

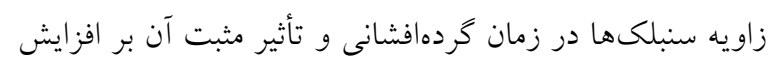
لقاح و بارورى بهدنبال كاربرد تنظيم كندههاى رشد مىتواند بـــ ازدياد تعداد دانه در هر سنبله منجر شود. مترمربع انجام و جهت اندازهذيرىهـاى لازم بـهـ آزمايشـحاه

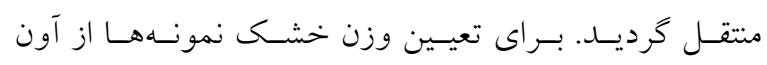
تهويسهدار در دمـاى •م درجسه سـانتى خــــاد اسـتفاده شـــ و شاخص برداشت از نسبت درصد عملكرد دانسه بـه عملكـرد بيولوزيك محاسبه كرديد. در نهايت دادههاى جمع آورى شده با استفاده از نرمافزارSAS مورد تجزيه و تحليل آمـارى قـرار

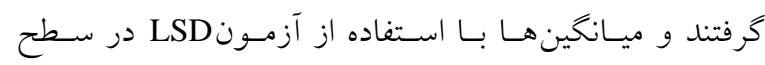

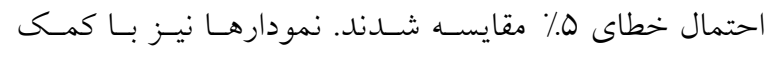
نرمافزار Excel Eمسم كرديد. 


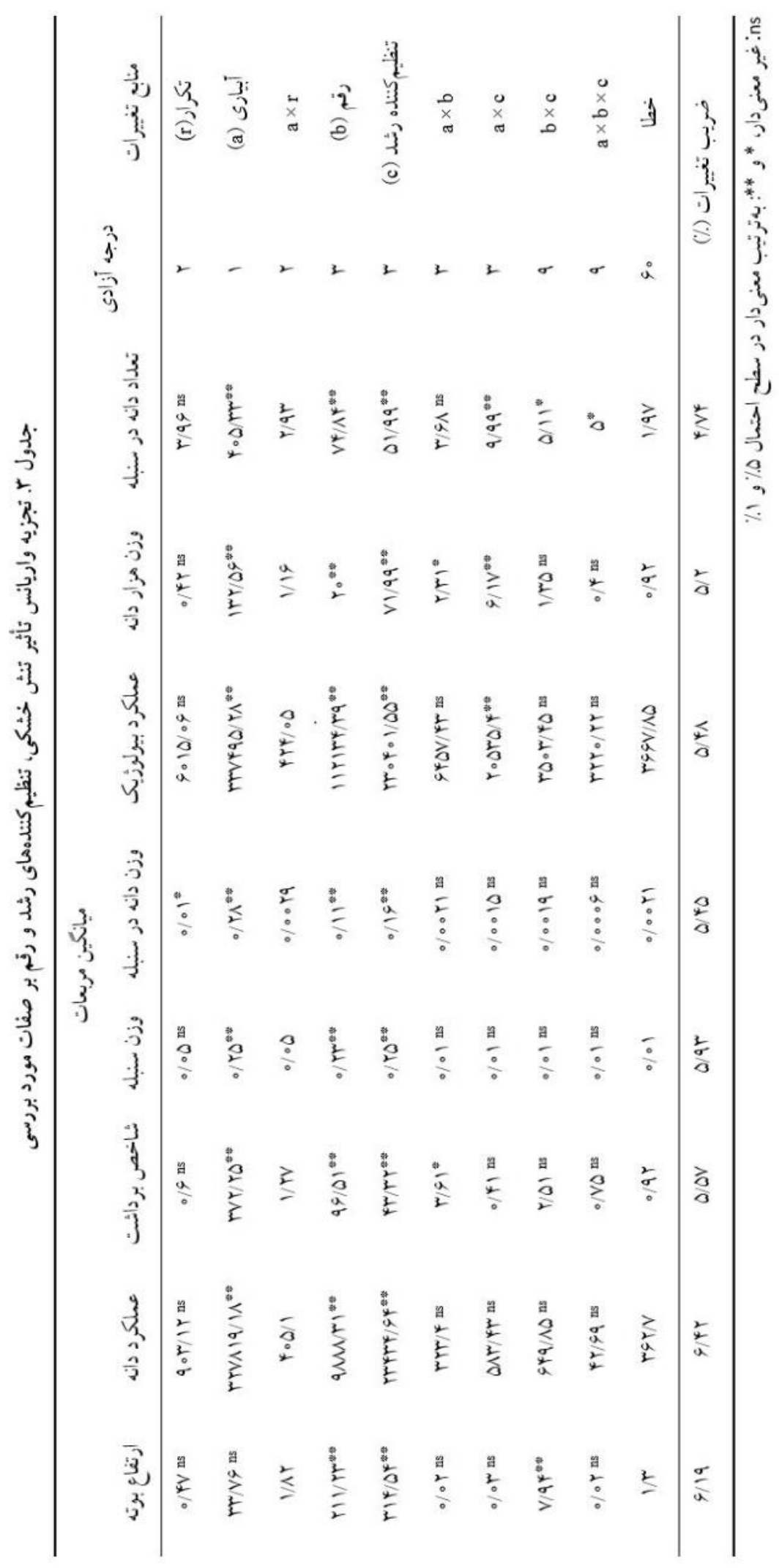


نشريه توليد و فرآورى محصولات زراعى و باغى / سال ششم / شماره بيست و يكم / باييز هوسا

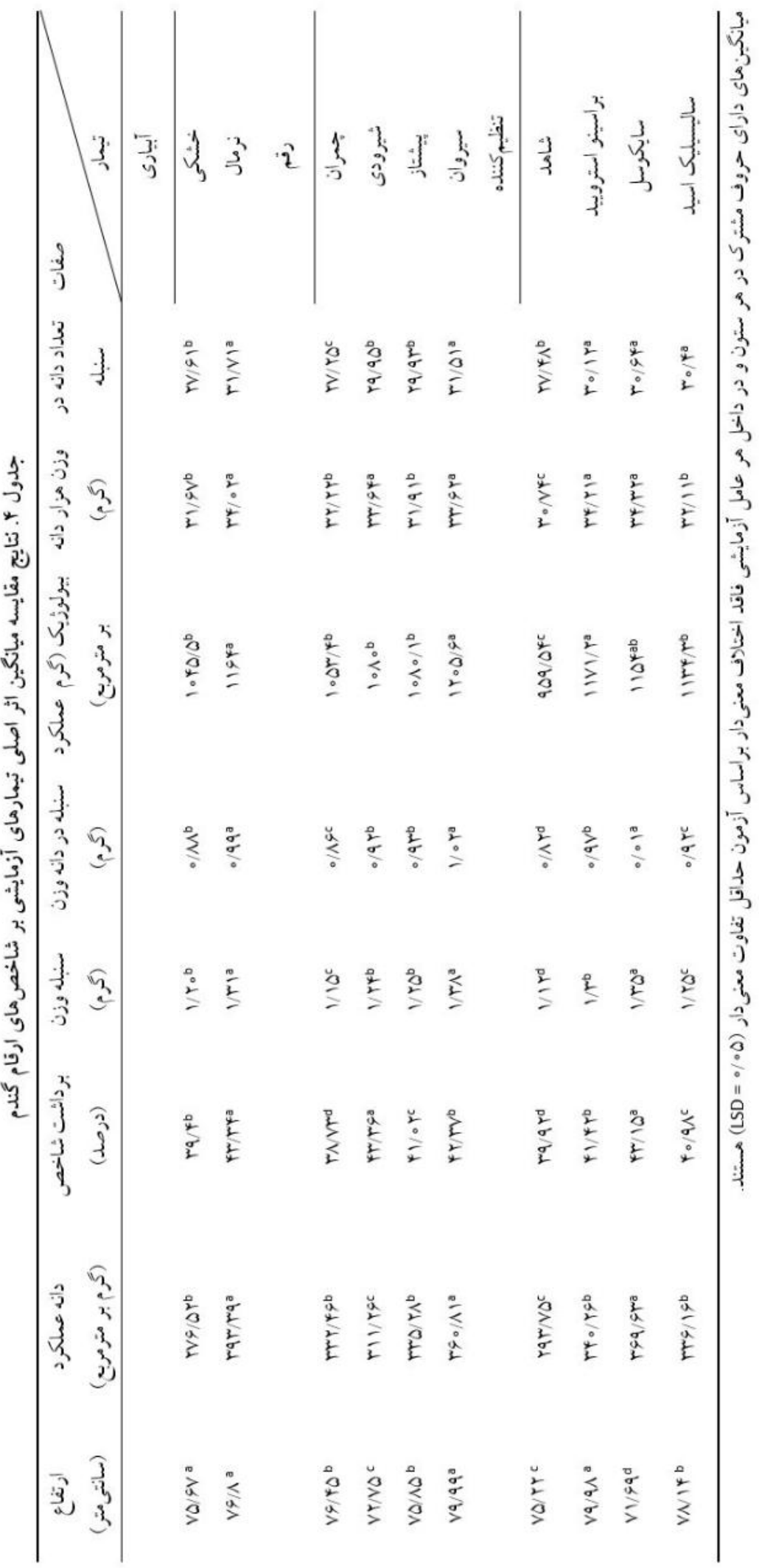


ساير مقصدهاى فيزيولوزيك پِ از قطع آبيارى باشـــ بنـابراين

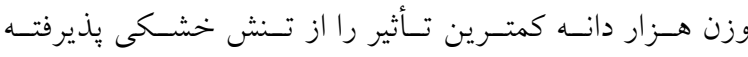

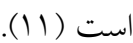

در بين تنظيمكننده هاى رشد، سايكوسل بيشترين تأثير را

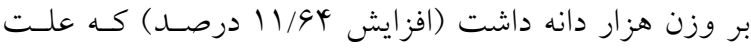

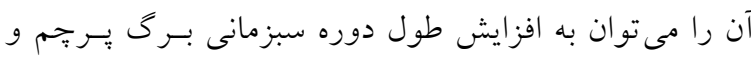

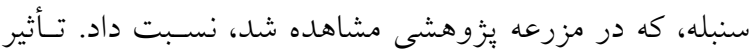
مثبت سايكوسل بر وزن هزار دانه با نتايج راجـالا و سـاينييو

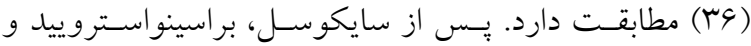
سالسيليك اسـيد بـــترتيـب باعـث افـزايش وزن هـزار دانـهـ

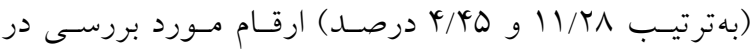
مقايسه با تيمار شاهد نشان شدند. در بين تنظيم كنــدهــاى

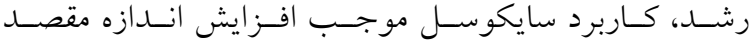

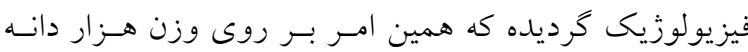

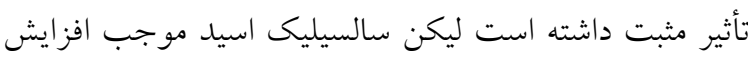
فتوسنتز برى و جريان بهتر مواد برورده در كياه مىشود كـهـ اين موضوع مىتواند به ير شدن مطلوبتر دانهها منجر شـود

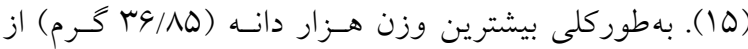
رقم سيروان با تيمار سايكوسل در شـرايط آبيـارى نرمـال و

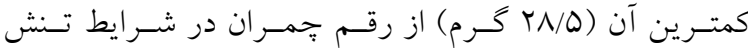
خشكى و عدم مصرف تنظيمكنندهاى رشد در تيمـار تـنش

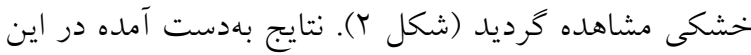

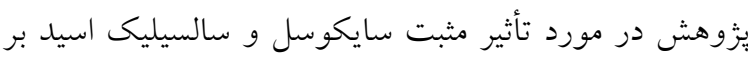

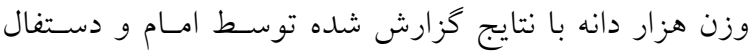

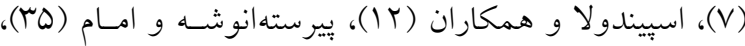
جيريايى و همكاران (19) و شـكوفا و امـام (4) همخــوانى

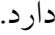

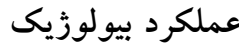

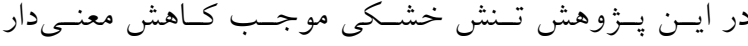

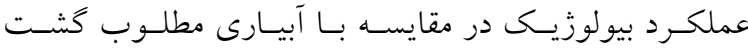

با كاربرد سايكوسل تسهيم مواد برورده به رشد رويشى كمتـر

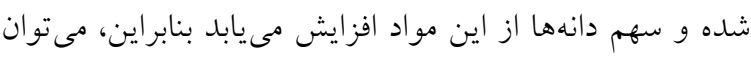

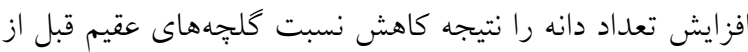
حـردهافشـانى دانسـت. حيـات و همكــاران (19) نيـزنقش تعديل كندكى ساليسيليك اسيد بر اثر تنش خشكى در كـاهش تعلداد دانه را گز ارش كردهاند. تعــاد دانسه در سـبـله بـا ازديـاد اندازه مقصد فيزيولوزيكى نقش مستقيمى در عملكرد دانسه دارد،

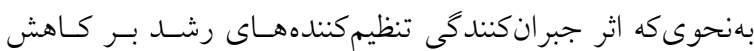
تعداد دانه در سنبله تحت شر ايط تنش خشكى، مى توانـــ منجـر

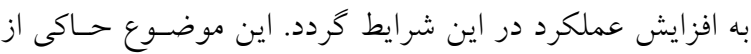

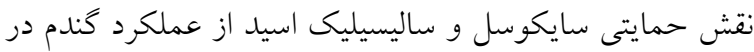
شرايط تنش خشكى مىباشد (Tr).

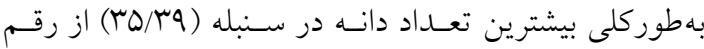

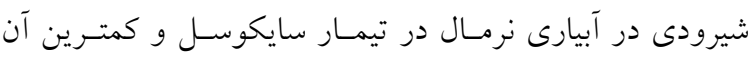

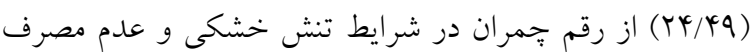
تنطيم كننده بهدست آمد (شكل ()).

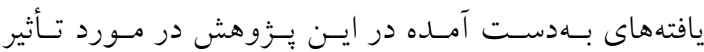

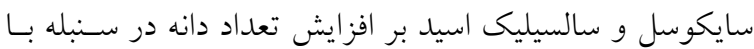

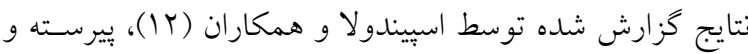

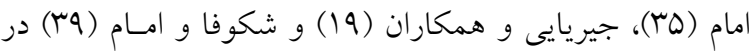

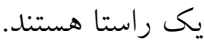

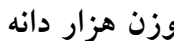

در اين يزّوهش تنش خشكى موجب كاهش معنى دار (V درصد)

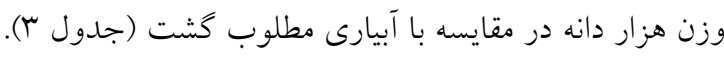

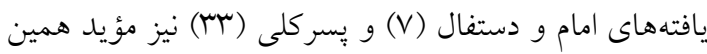

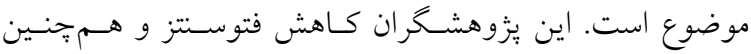
تسريع در رسيدن دانه راعلت كاهش ميـانخين وزن هـزار دانـهـ كزارش كردهاند. هم جنـين در شـرايط تـنش خشـكى بـه نظـر

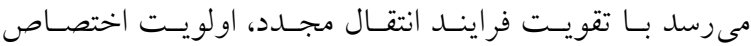
مواد يرورده ذخيـره شــهه در بوتـهــا، دانسهــا در مقايسـه بـا 
نشريه توليد و فرآورى محصولات زراعى و باغى / سال ششم / شماره بيست و يكم / پاييز هوها

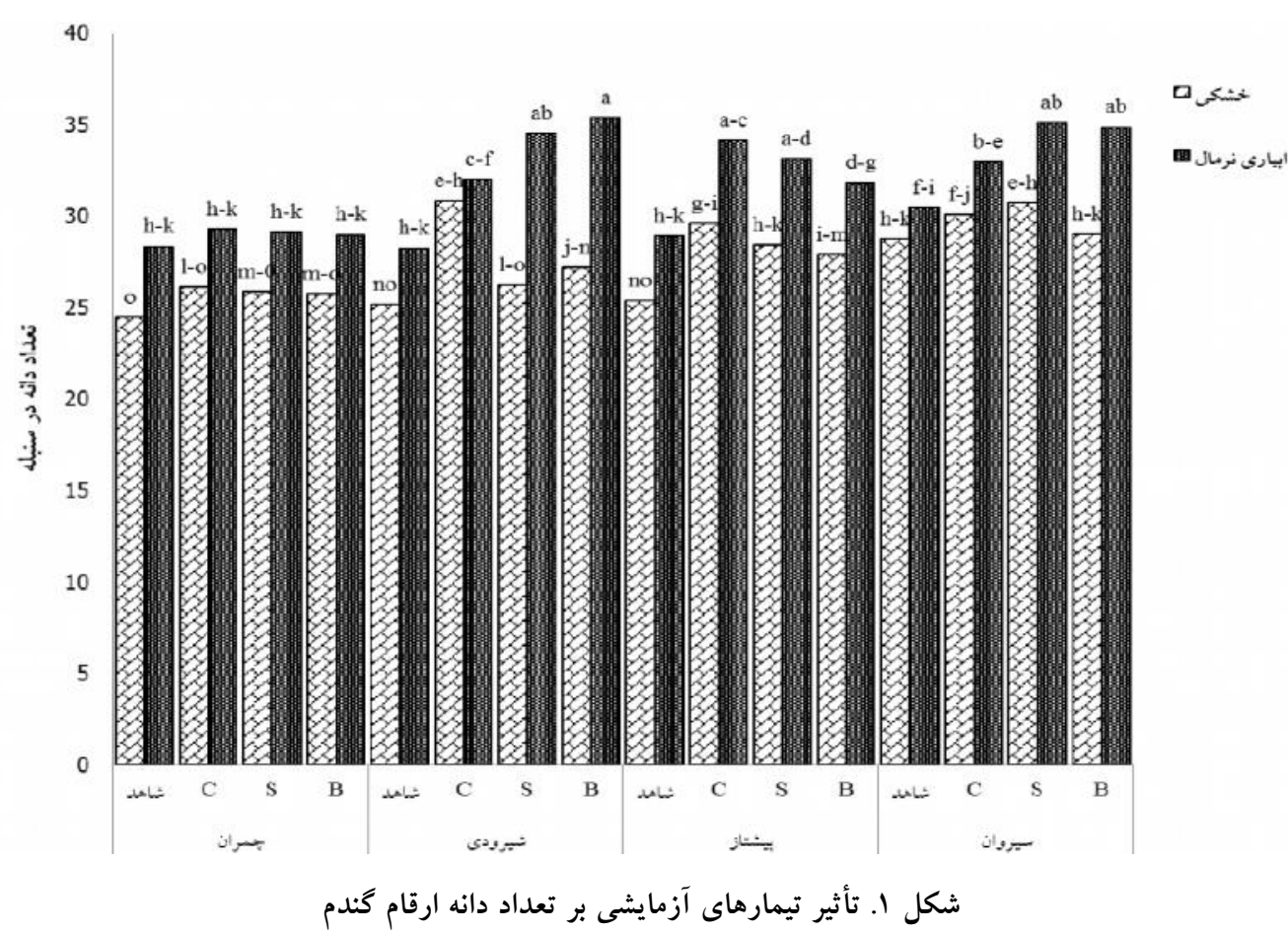

حروف مشابه در هر ستون نشاندهنده عدم وجود اختلاف معنىدار براساس آزمون حداقل تفات معنىدار (LSD = 0.05$)$ مىباشد. (C)

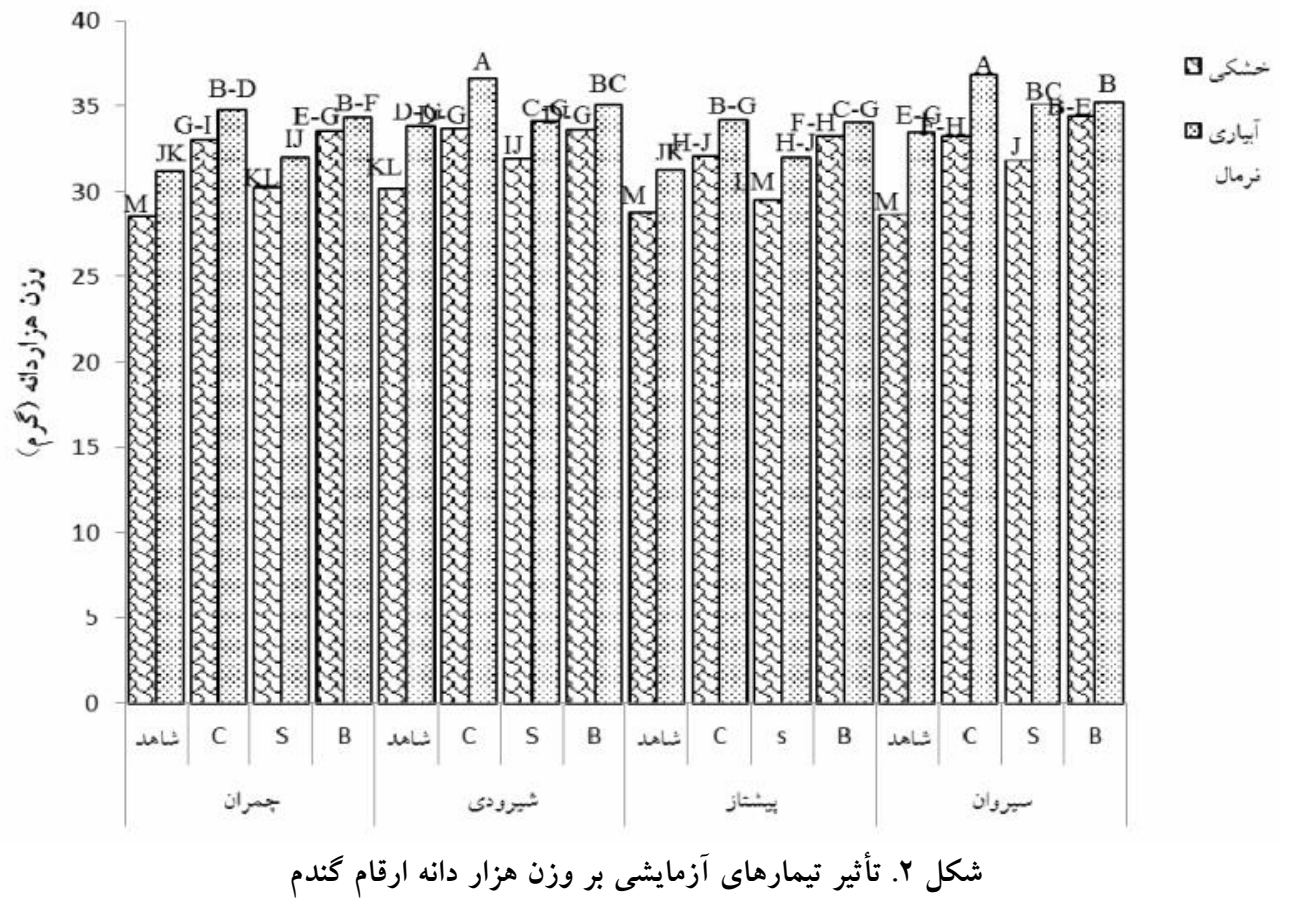

حروف مشابه در هر ستون نشاندهنده عدم وجود اختلاف معنىدار براساس آزمون حداقل تفات معنىدار (LSD = 0.05) مىباشد. (C) 
و كمترين آن ( VAV/D9 كَرم در مترمربـع) در رقـم جمهـران در شرايط تنش خشكى در زمان عدم مصرف تنظيم كننده مشـاهده شد (شكل r).

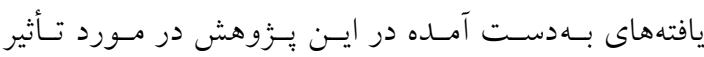
مثبت سالسيليك اسـيد بـر روى عملكـرد بيولوزيـك بــا نتـايج

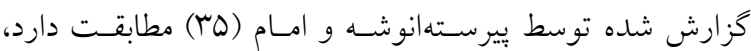

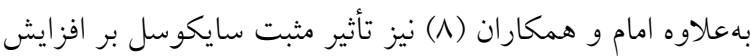

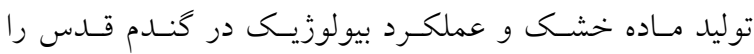

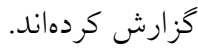

\section{ميانگين وزن دانه در سنبله}

در اين يزوهش تنش خشكى موجب كاهش معنى دار وزن دانسه

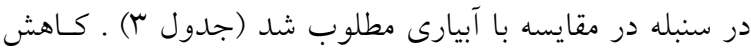

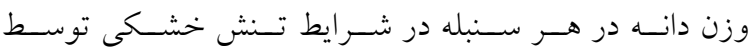

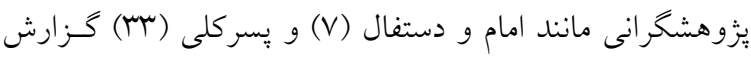

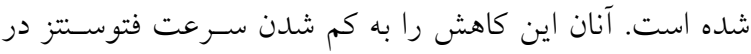
كياه و هم جنين كاهش انتقال مواد برورده در كياه و تسـريع در بـ رسيدن دانهها نسبت دادهاند. در بين تنظيمكندههاى رشد سايكوسل بيشترين تأثير مثبـت

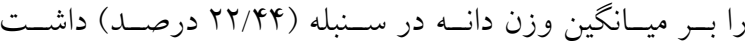
(جدول \&) كه ممكن است در ارتباط با افزايش مدت سـبزمانى

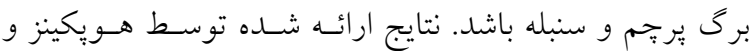

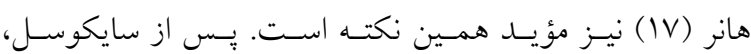

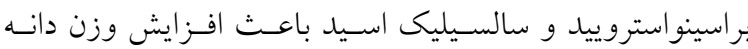
در سنبله (بهترتيب K/Y و IT/TV درصد) ارقام مـورد بررسى

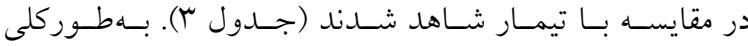
بيشترين ميانخين وزن دانه در سنبله از رقـم سـيروان بـا تيمـار سايكوسـل (M/ آكـرم) در شـرايط آبيـارى نرمـال و كمتـرين آن از رقم جزمـران در شـرايط تــش خشـكى و عــدم مصـرف

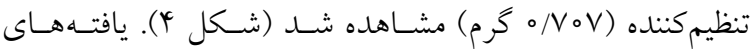
بهدست آمده در اين بزّوهش در مورد تأثير مثبـت سايكوسـل
(جدول r). عملكرد بيولوزيك شامل وزن خشك تمام انــام

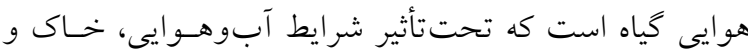
كَياه قرار مى گيرد (19) و تنش خشكى از راههاى مستقيم و غير مستقيم (مانند كاهش سطح برى، كـاهش تورزسـانس و و

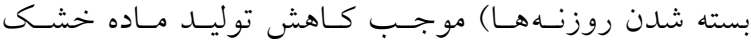

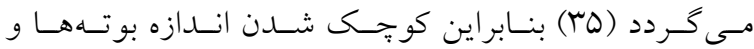
كاهش توليد ماده خشك منجر به افـت عملكـرد بيولوزيـى

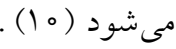
كرجه در بين تنظيم كنندهاى رشد براسينواستروييد تـأثير

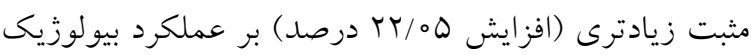
داشت ليكن تفاوت آن از لحاظ آمارى با سايكوسل (افزايش

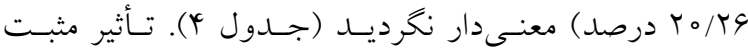

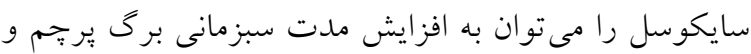
سنبله كه توليد بيشتر ماده خشك را در يسى دارد نسـبت داد.

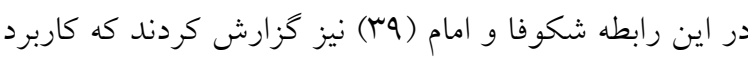

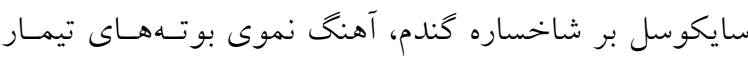

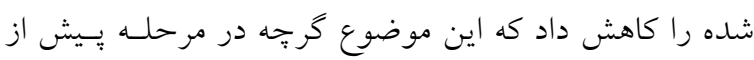
كل شكفتخى با كاهش تجمع ماده خشك (بهصورت موقـت ) همراه بود، ليكن، پِس از مرحله كل دهى اين رونـــ معكـوس كرديد، بهنحوى كه وزن خشك بوتههـا نسـبت بـه شـاهد در

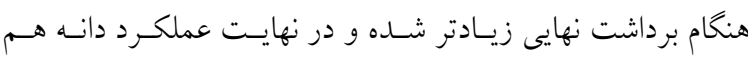

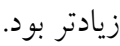
بِ از از براسينواستروييد و سايكوسل، سالسيليك اسـيد نيـز

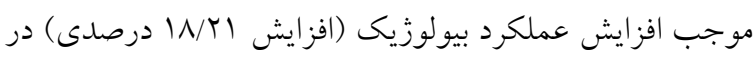

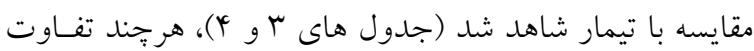

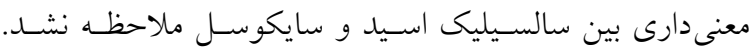

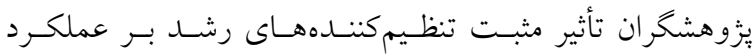

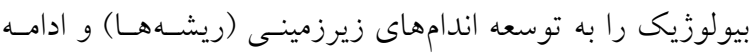
فر ايند فتوستز تحــت تـنش خشكى و در نهايـت توليـــ مـاده خشك بيشتر در اين شرايط نسبت دادهانـــ (ما و هَ). در بسين

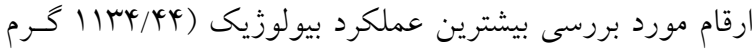
در مترمربع) از رقم سيروان با تيمار سايكوسل در آبيارى نرمال 


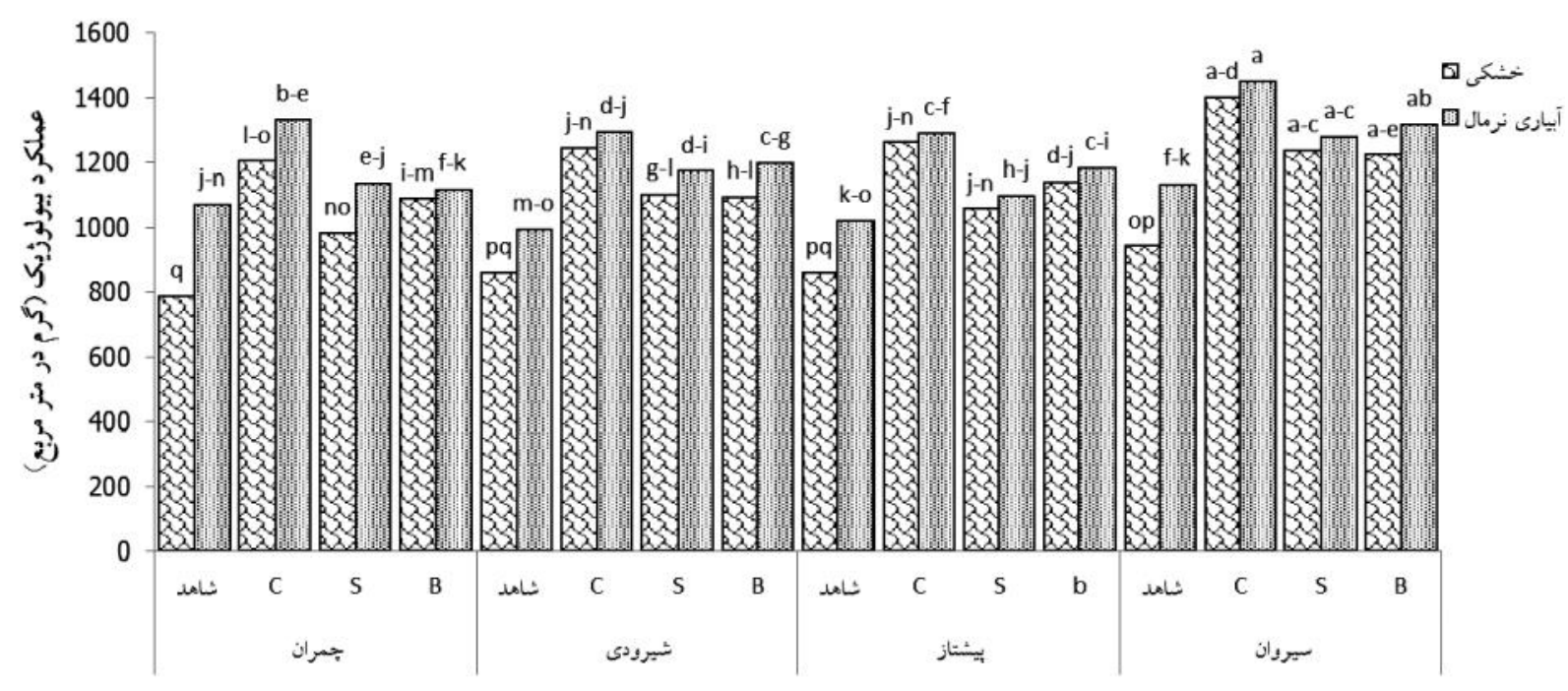

$$
\begin{aligned}
& \text { شكل r. تأثير تيمارهاى آزمايشى بر عملكرد بيولوزيك ارقام گندم } \\
& \text { حروف مشابه در هر ستون نشاندهنده عدم وجود اختلاف معنىدار براساس آزمون حداقل تفات معنىدار (LSD = 0.05) مىباشد. } \\
& \text { (C) }
\end{aligned}
$$

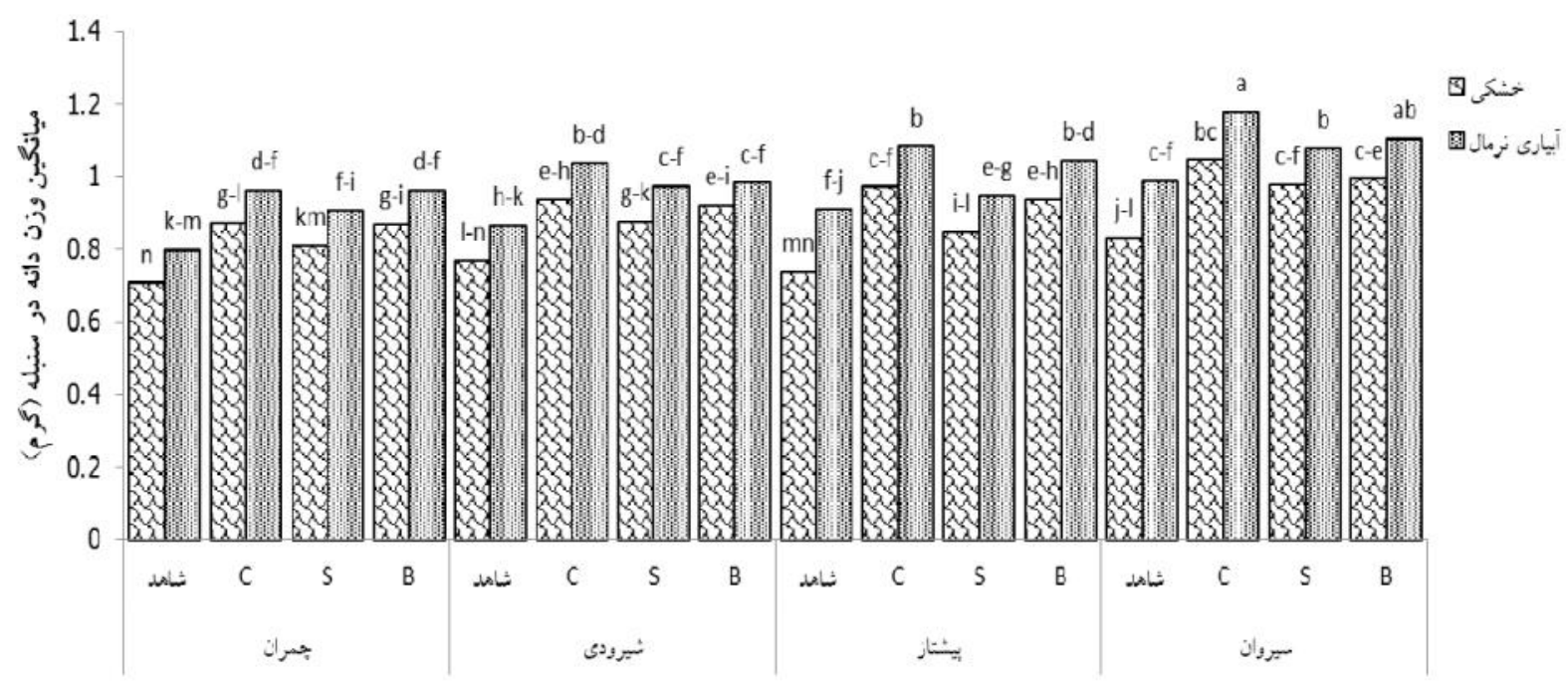

$$
\text { شكل Fا. تأثير تيمارهاى آزمايشى بر وزن دانه در سنبله }
$$

حروف مشابه در هر ستون نشاندهنده عدم وجود اختلاف معنىدار براساس آزمون حداقل تفات معنىدار (LSD = 0.05) مىباشد. (C)

$$
\text { و سالسيليك اسيد بر ميانخين وزن دانه در سنبله با نتايج كزارش ميانگين وزن سنبله }
$$

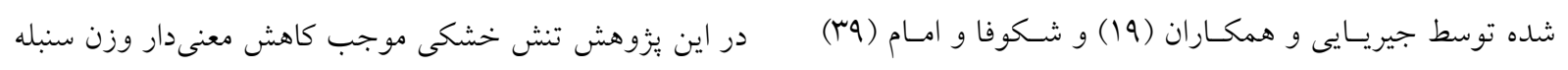
(درصد در مقايسه با آبيارى مطلوب كرديد (جدولهـاى V/VN) مطابقت دارد . 
برداشت (9/09 درصد) در مقايسه بـا آبيـارى مطلـوب كثـت (جدول r) كه اين كاهش را مى تـوان بـه كـاهش وزن دانـه در سنبله، تعداد دانه در سنبله و ميانگين وزن هر سنبله نسـبت داد. نتايج اسييندولا و همكاران (I I) و بييرستهانوشه و امام (ه) نيز نتايج يزوهش حاضر را تأييد مى كند. استفاده از تنظيم كنندهاى رشد، حتى با حفظ مـاده خشـك توليد شده، از راه ازدياد شاخص برداشت مىتواند بــه افـزيش عملكـــرد منجـــر شــود (11). در يــزوهش حاضــر از بــين تنظيم كنندهاى رشد سايكوسل بيشـترين تـأثير را بـر شـاخص

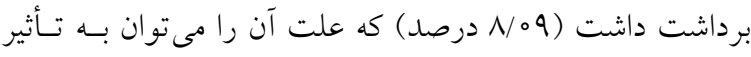
سايكوسل بر افزايش وزن سنبلهها وعملكرد دانسه نسـبت داد و به همين دليل تأثير سايكوسل بر شاخص برداشت گندم مثبت و افزايشسى بـوده اسـت. يسس از سايكوسـل، براسينواسـتروييد و سالسيليكى اسـيد بــهترتيـب باعـث افـزايش معنسى دار شـاخص برداشت (بهترتيب Y/9 و T/9 درصد) ارقـام مـورد بررسسى در مقايسه با تيمار شاهد نشان دادند (جدول \&). يزٔوهشخران ايسن موضوع را به افزايش مقاومت به تـنش هــاى محيطى بـا حفظظ محتواى آب برگ و كاهش نشت يونى (r و 19) در اين شرايط نسبت دادهاند. بهطوركلى بيشـترين شـاخص برداشـت از رقـم

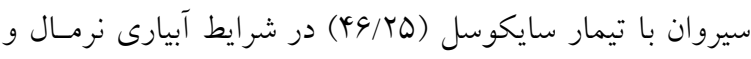

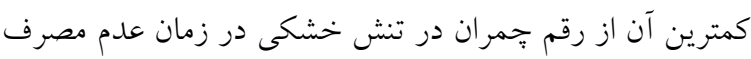

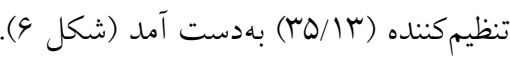
يافتهاى بهدست آمده در اين بزوهش در مورد تأثير مثبـت سايكوسل و سالسيليك اسيد بر روى شاخص برداشت با نتـايج

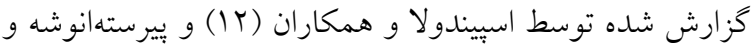
امام (هץ) در يك راستا است.

عملكرد دانه جدول مقايسه ميانگين ها حاكى از وجود برترى M/V درصــى عملكرد دانـه در تيمـار آبيـارى نرمـال بــود (جـــول \&). افـت عملكرد دانه در شرايط تنش خشكى بههمـراه كـاهش عملكــــ
ץ و ؟ ). كاهش وزن سنبله در شرايط تنش خشكى نتيجه كاهش فتوسنتز بوتها در اين شرايط بوده كه مورد توجه يزوهشخرانى نظير امام و ثقهالاسلامى ( ا1) و بيرستهانوشـه و امـام (هم) نيـز قرار گرفته است. در بين تنظيم كنـــههـاى رشـد، سايكوسـل بيشترين تأثير مثبت را بر ميانخين وزن سنبله (هه// داشت (جدول \&) كه علت آن را مى توان بـهـ افـزايش مــدت سبزمانى برگ يرجم و سنبله نسبت داد و نتـايج ارائسه شـده توسط هويكينز و هـانر (IV) نيـز مؤيسا همـين نكتـه اسـت بنابراين، به نظر مىرسد محلـولياشـى سايكوسـل از طريستق كاهش ارتفاع بوتها و افزايش طول ريشهها، زمينه لازم براى افـزايش جـــب آب و عناصـر غــايى فــراهم نمـوده باشـــ كه اين موضوع منجر به افـزايش فتوسـنتز شـده و در نتيجـهـ مواد فتوسنتزى بيشـترى بــراى انــامهــاى هـوايى از جملـهـ سنبله، كه مقصد فيزيولويكى قـوى مسىباشــ، فــراهم نمـوده

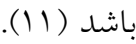
يس از سايكوسل، براسينواستروييد و سالسيليك اسيد نيز

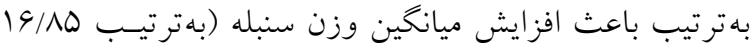
و 11/91 درصد) ارقام مورد بررسى در مقايسه با تيمار شاهد شدند كـه ايسن موضـوع را مسى تـوان بـهـ حفـظ فراينـدهاى

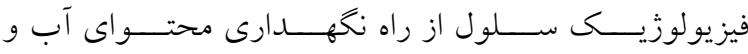
افـز ايش مقاومست بـهـ تــش هــاى محيطى نســبت داد ( (1). بهطوركلى بيشترين ميانخين وزن سنبله از رقم سيروان با تيمـار سايكوسل (1/1/ گرم) در شرايط آبيارى مطلوب و كمتـرين آن

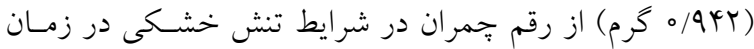
عدم استفاده از تنظيم كننده مشاهده شــ (شـكل ه). يافتـهـــاى بهدست آمده در اين بيزوهش در مورد تأثير مثبت سايكوسـل و سالسيليك اسيد بر ميانگين وزن سنبله با بيش از اين نيز توسط جيريايى و همكاران (19) و شكوفا و امام (وس) خـزارش شـده است شاخص برداشت در اين يُزوهش تنش خشكى موجب كاهش معنسى دار شـاخص 
نشريه توليد و فرآورى محصولات زراعى و باغى / سال ششم / شماره بيست و يكم / پاييز هه؟1

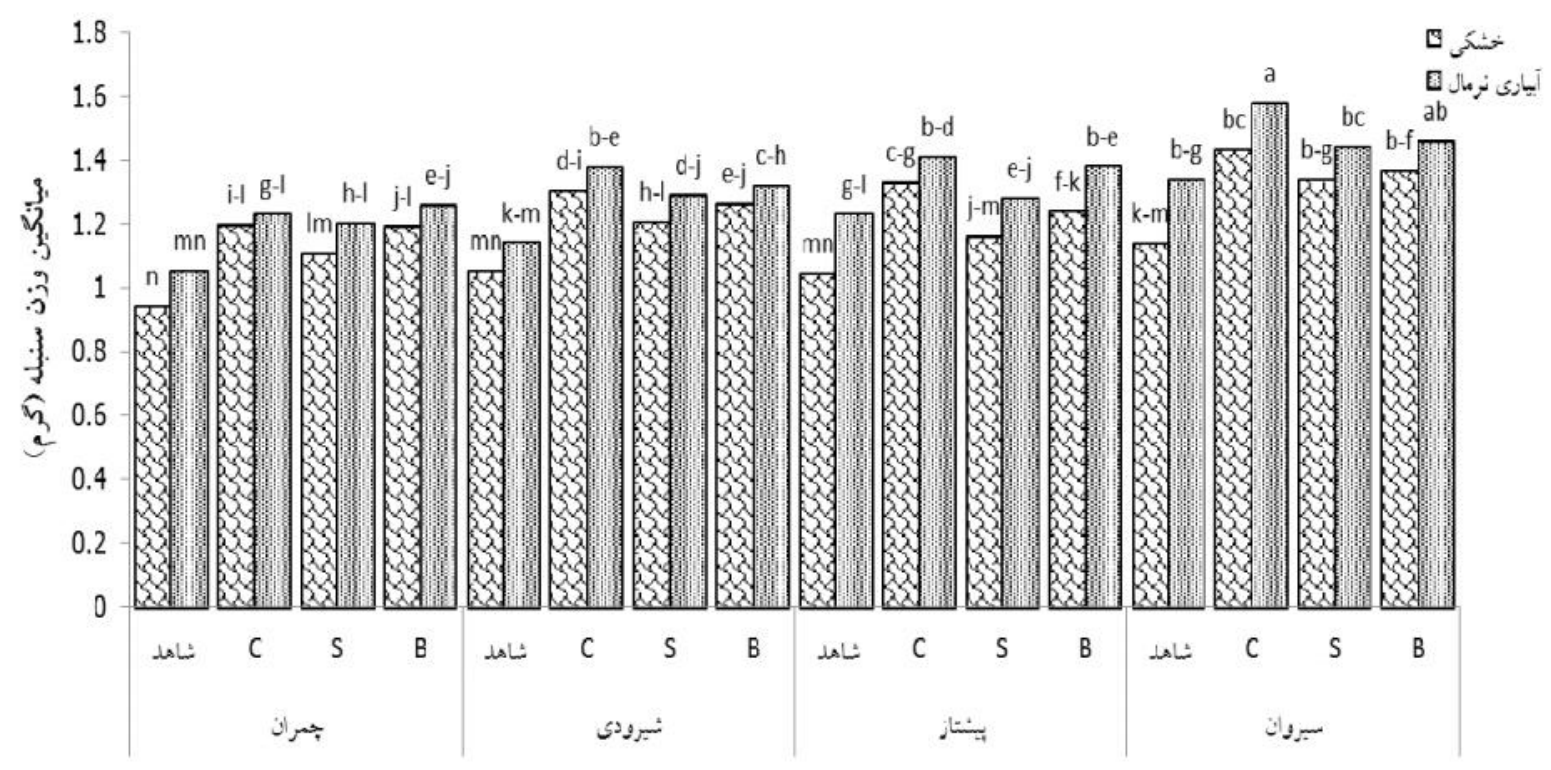

$$
\begin{aligned}
& \text { شكل ه. تأثير تيمارهاى آزمايشى بر ميانخين وزن سنبله } \\
& \text { حروف مشابه در هر ستون نشاندهنده عدم وجود اختلاف معنىدار براساس آزمون حداقل تفات معنىدار (LSD = 0.05) مىباشد. } \\
& \text { (C): سايكوسل، S: سالسيليك اسيد و B: براسينواستروييد مىباشد.) }
\end{aligned}
$$

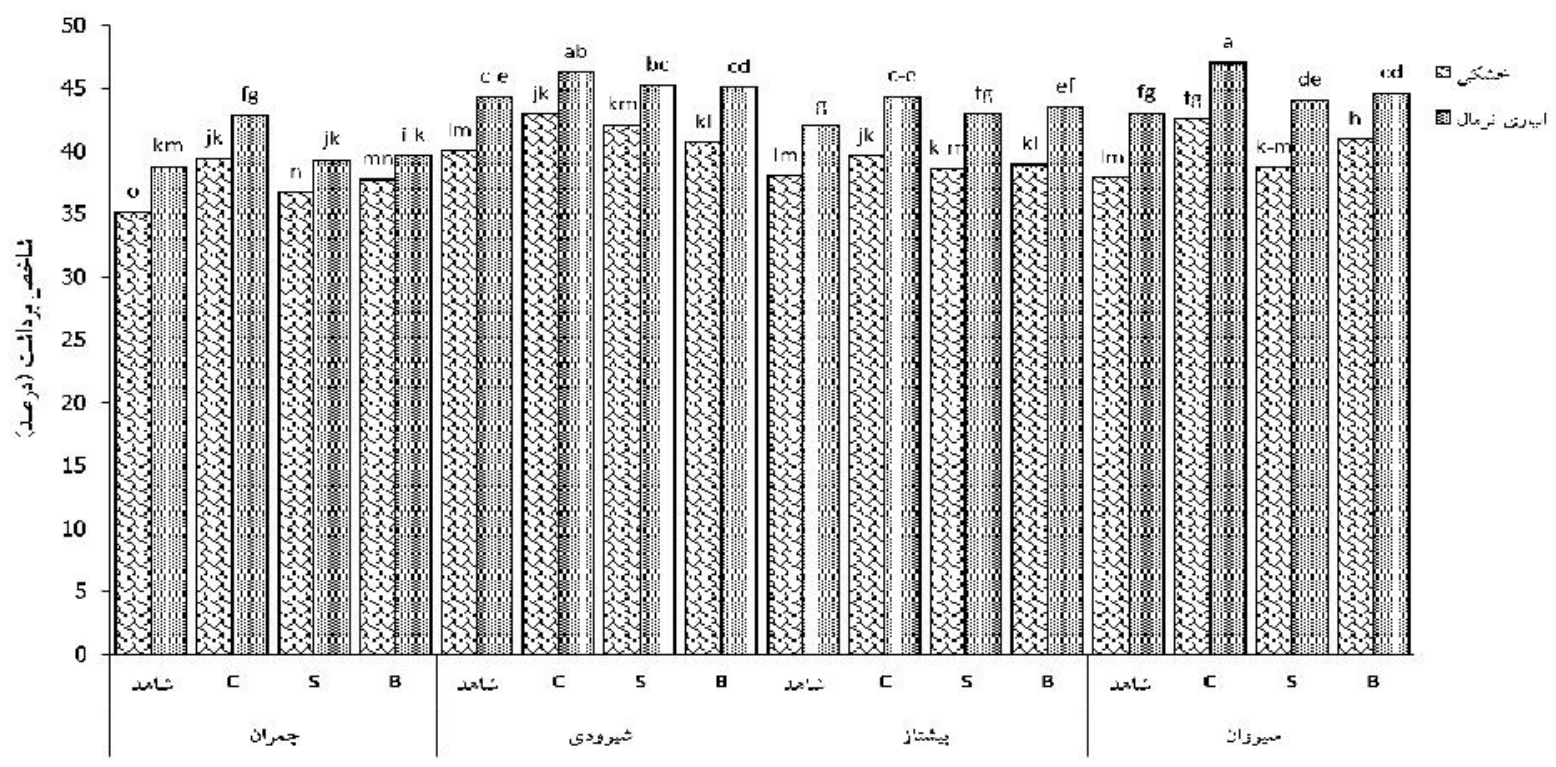

$$
\begin{aligned}
& \text { شكل و. تأثير تيمارهاى آزمايشى بر شاخص برداشت ارقام گندم } \\
& \text { حروف مشابه در هر ستون نشاندهنده عدم وجود اختلاف معنىدار براساس آزمون حداقل تفات معنىدار (LSD = 0.05) مىباشد. } \\
& \text { (C): سايكوسل، S: سالسيليك اسيد و B: براسينواستروييد مىباشد.) }
\end{aligned}
$$




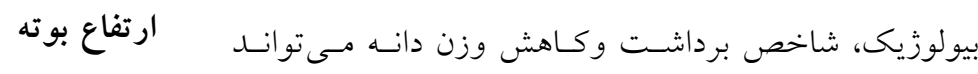

در هر دو شرايط آبيـارى نرمـال و تسنش خشـكى بيشـترين

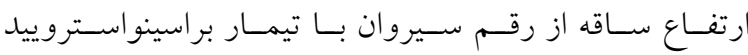

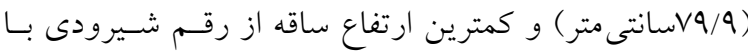
تيمار سايكوسل (VI/9 سانتىمتر) مشاهده گرديد (شكل A).

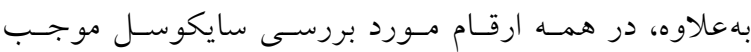

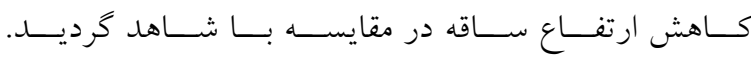
براسينواستروييد و ساليسيليك اسيد بهترتيب بيشترين تأثير را

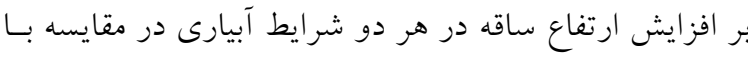

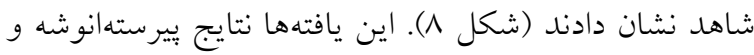

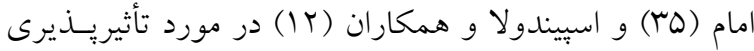

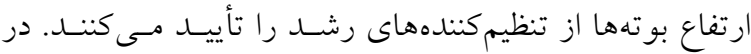

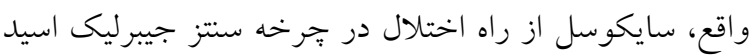

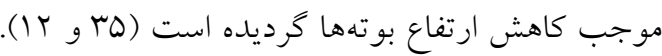

\section{نتيجه گيرى}

يزّوهش حاضر نشان داد كه تنش خشكى آخر فصل موجـب

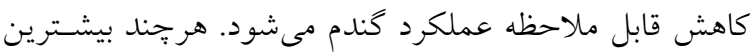
نتايج مثبت كاربرد استفاده از تنظيمكنندهاى رشد بر عملكرد

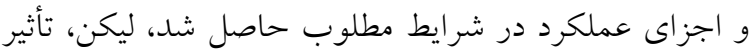

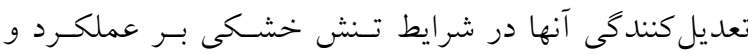

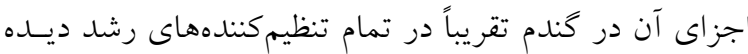
شد كه مىتواند در يزوهشهاى مزرعهاى بعدى مورد توجسه

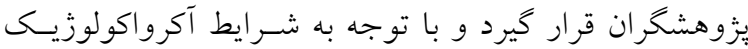
هر منطقه تيمارهاى مناسب تعيين و بهكـار كرفتـه شـوند. در

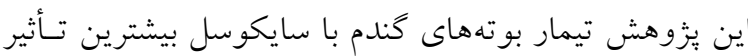

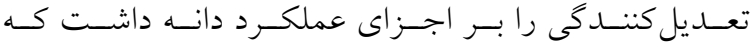
يُزوهشهاى تكميلى در اين راستا قابل توصيه است.
برآيند كاهشى فرايندهاى فيزيولوزيك تشكيل دهنده عملكرد از قبيل فتوسنتز، انتقال ماده خشك در كياه و تخصيص بيشتر

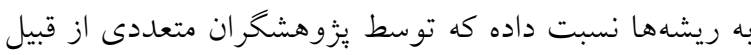

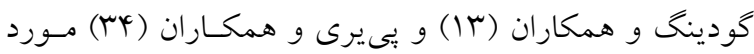

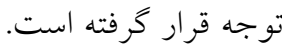

در بين تنظيمكنندهاى رشد، سايكوسل بيشترين تـأثير را

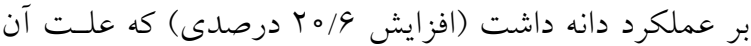

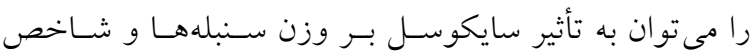

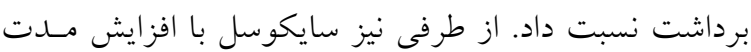

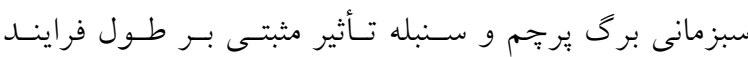
فتوسنتز داشته است. نتايج ارائه شده توسط بيرستهانوشـه و امام (rQ) و شكوفا و امــام (T) نيـز مؤيســ همسين موضـوع است. بِ از سايكوسل، براسينواستروييد بيشترين تأثير را بر

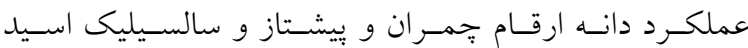

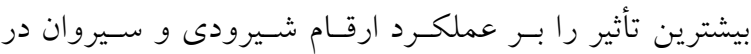
مقايسه با تيمار شاهد بهجا كذاشت كه اين موضسوع رامس نس توان به تفاوت سير مراحل فيزيولوزيكى ايسن ارقـام و طـول دوره رشد آنها نسبت داد. افزايش عملكرد توسط سايكوسل فـل و ساليسيليك اسيد را مى توان به اثر مثبت و افزاينده آنها بـر اجزاى عملكرد دانه مانــــ وزن هـزار دانـه و تعــاد دانـه در

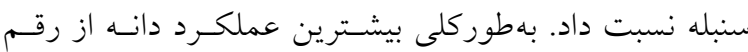
سيروان با تيمار سايكوسل در شرايط آبيارى نرمال (SOS/9V

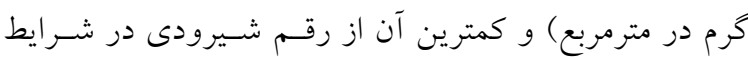

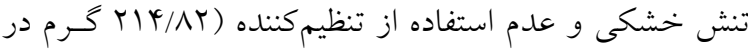

$$
\text { مترمربع) مشاهده كرديد (شكل V) }
$$

يافتههاى بهدست آمده در ايسن يـرزوهش در مـورد تـأثير مثبت سايكوسل و سالسيليك اسـيد بـر روى عملكـــد دانسه،

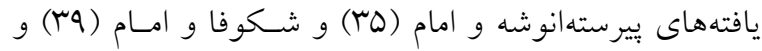

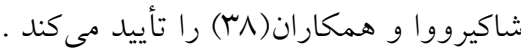


نشريه توليد و فرآورى محصولات زراعى و باغى / سال ششم / شماره بيست و يكم / پاييز هوها

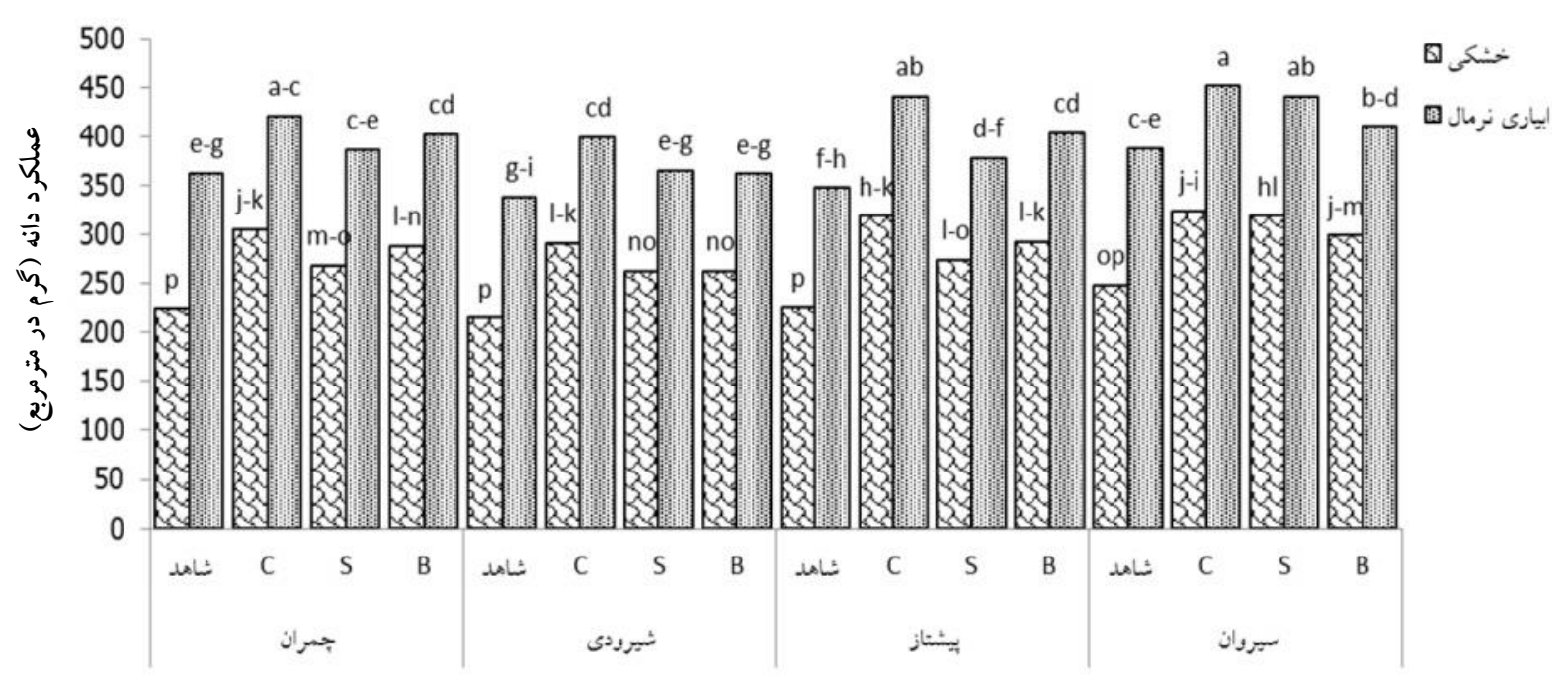

شكل V. تأثير تيمارهاى آزمايشى بر عملكرد دانه ارقام كندم

حروف مشابه در هر ستون نشاندهنده عدم وجود اختلاف معنى دار براساس آزمون حداقل تفات معنىدار (LSD = 0.05) مى باشيد.

(C)

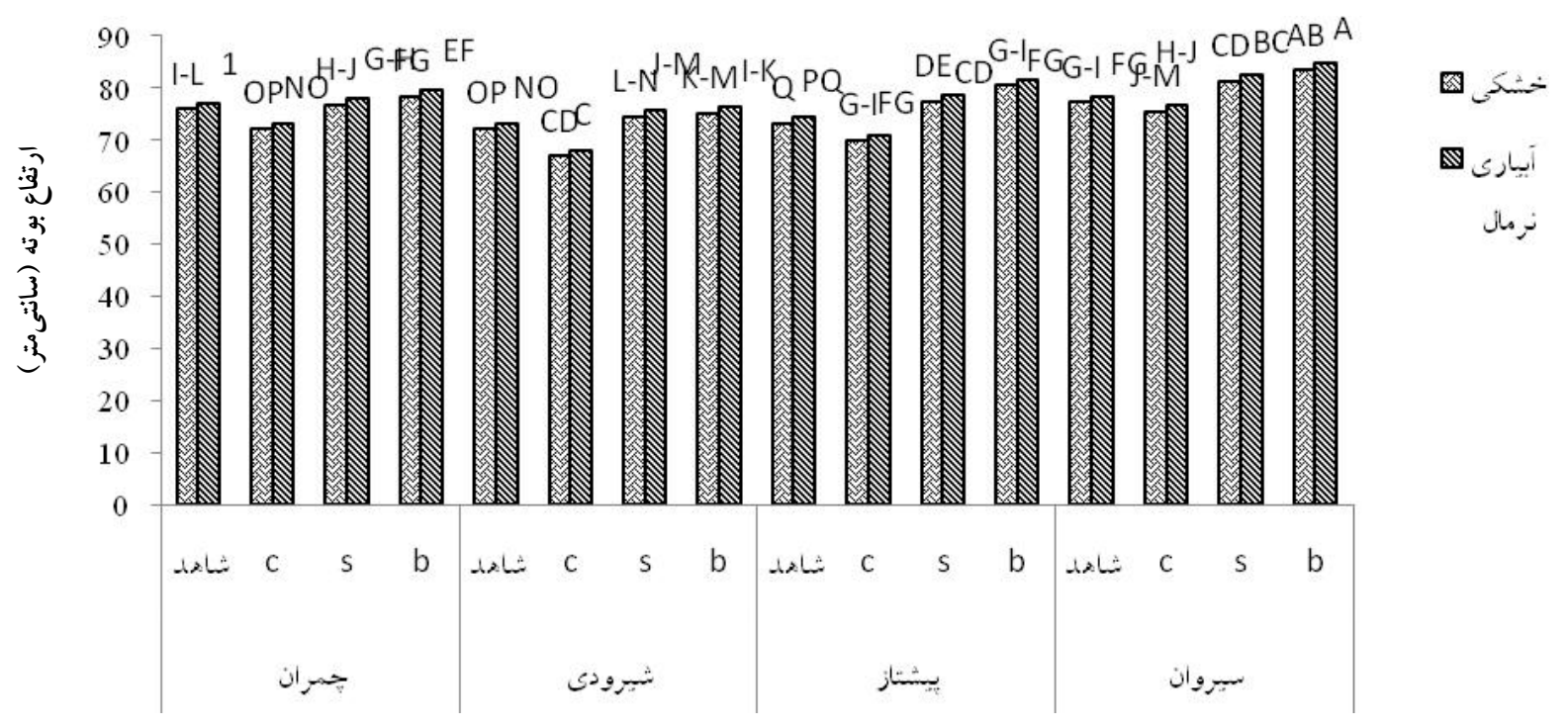

شكل مـ تأثير تيمارهاى آزمايشى بر ارتفاع بوته ارقام گندم

حروف مشابه در هر ستون نشاندهنده عدم وجود اختلاف معنىدار براساس آزمون حداقل تفاوت معنىدار (LSD = 0.05) مى بـاشد.

(C) 
1. Altenbach, S. B., F. M. DuPont, K. M. Kothari, R. Chan, E. L. Johnson and D. Lieu. 2003. Temperature, water and fertilizer influence the timing of key events during grain development in US Spring wheat. Journal of Cereal Science 37: 9-20.

2. Ashraf, M., N. A. Akram, R. N. Arteca and M. R. Foolad. 2010. The physiological, biochemical and molecular roles of brassinosteroids and salicylic acid in plant process and salt tolerance. Critical Reviews in Plant Science 29: 162190.

3. Bartels, D. and R. Sunkar. 2005. Drought and salt tolerance in plants. Critical Reviews in Plant Science 24: 23-58.

4. Chegeni, H. 2011. Effect of plant density on yield and yield components of wheat cultivars. Agronomy Journal (Pajouhesh and Sazandegi) 104:9-21. (In Farsi).

5. Cheong, Y. H., K. N. Kim, G. K. Pandey, R. Gupta, J. J. Grant and S. Luan. 2003. CLB1, a calcium sensor that differentially regulates salt, drought, and cold responses in Arabidopsis. The Plant Cell 15: 1833-1845.

6. Emam, Y., E. Tafazoli and H. R. Karimi. 1996. Growth and development of winter wheat (cultivar Ghods) as affected by chlormequat chloride (CCC). Iranian Journal of Agricultural Science 27 (1) 23-31. (In Farsi).

7. Emam, Y. and M. Dastfal. 1997. Above and below ground responses of winter barley plants to Chlormequat in moist and drying soil. Crop Research 14: 457-470.

8. Emam, Y. and H. R. Karimi. 1996. Influence of chlormequat chloride on five winter barley cultivars. Iran Agricultural Research 15:89-109. (In Farsi).

9. Emam, Y. and G. R. Moaied. 2000. Effect of planting density and chlormequat chloride on morphological characteristics of winter barley cultivar "Valfajr". Journal of Agricultural Science and Technology 2:75-83.

10. Emam, Y. and M. J. Seghatoeslami. 2005. Crop Yield, Physiology and Processes. Shiraz University Press, Shiraz. (In Farsi).

11. Emam, Y. 2010. Cereal Production. Shiraz University Press, Shiraz. (In Farsi).

12. Espindula, M. C., V. S. Rocha, J. A. S. Grossi, M. A. Souza, L. T. Souza and L. F. Favaroto. 2009. Use of growth retardants in wheat. Planta Daninha 27(2): 379-387.

13. Gooding, M. J., R. H. Ellis, P. R. Shewry and J. D. Schofield. 2003. Effects of restricted water availability and increased temperature on grain filling, drying and quality of water wheat. Journal of Cereal Science 37: 295-309.

14. Grove, M. D., G. F. Spencer, W. K. Rohwedder, N. B. Mandava, J. F. Worley and J. D. Wathen. 1979. Brassinolide a plant growth promoting steroid isolated from Brassica napus pollen. Nature 281: 216-217.

15. Hayat, S. and A. Ahmad. 2007. Salicylic Acid - A Plant Hormone. Springer. ISBN 1402051832. Netherlands.

16. Hayat, Q., S. Hayat, M. Irfan and A. Ahmad. 2009. Effect of exogenous salicylic acid under changing environment: A Review. Environmental and Experimental Botany 134: 1-12.

17. Hopkins W. G. and N. P. Huner. 2004. Introduction to Plant Physiology ( ${ }^{\text {rd }}$ Ed.). John Wiley and Sons. Inc. New York.

18. Hussein, M. M., L. K. Balbaa and M. S. Gaballah. 2007. Salicylic acid and salinity effects on growth of maize plants. Research Journal of Agriculture and Biological Sciences 3(4): 321-328.

19. Jiriaie, M., N. A. Sajedi, H. Madavi and M. Sheikhi. 2009. Effect of PGPR and water deficit on agronomical traits of wheat (cv. Shahriar). New Findings in Agriculture 3(4). 333-343. (In Farsi)

20. Ji, X., B. Shiran, J. Wan, D. C. Lewis, C. L. D. Jenkins, A. G. Condon, R. A. Richards and R. Dolferus. 2010. Importance of pre anthesis anther sink strength for maintenance of grain number during reproductive stage water stress in wheat. Plant Cell and Environment 33: 926-942.

21. Jung, J. and W. Rudemacher. 1983. Plant growth regulating chemicals in cereal grains. pp. 253-271. In: L. G. Nickell (Ed.), Plant Growth Regulating Chemicals, Vol. I, CRC Publication, Boca Raton, Florida.

22. Kang, H. M. and M. E. Saltveit. 2002. Chilling tolerance of maize, cucumber and rice seedlings leaves and roots are differently affected by salicylic acid. Physiologia Plantarum 115: 571-576.

23. Kaydan, D., M. Yagmur and N. Okut. 2006. Effects of salicylic acid on the growth and some physiological characters in salt stressed wheat (Triticum aestivum L.). Tarim Bilimleri Dergisi 13: 114-119.

24. Khripach, V. A., V. N. Zhabinskii and A. E. Groot. 1998. Brassinosteroids: A New Class of Plant Hormones. Acadamic Press. United States of America.

25. Khripach, V., V. Zhabinskii and A. E. Groot. 2002. Twenty years of brassinosteroidal plant hormones warrant better crops for the XXI century. Annals of Botany 80: 440-447.

26. Luigi, C., F. Rizza, B. Farnaz, E. Mazzucotelli, A. M. Mastrangelo, E. Francia, C. Mare, T. Alessandro and M. A. Stanca. 2008. Drought tolerance improvement in crop plants: An integrated view from breeding to genomics. Field Crops Research 105: 1- 14.

27. Maguire, J. D. 1962. Speed of germination aid in selection and evaluation for seedling emergence and vigor. Crop Science 2: 176-177. 
28. Maibangsa, S., M. Thangaraj and R. Stephen. 2000. Effect of brassinosteriod and salicylic acid on rice grown under low irradiance condition. Indian Journal Agricultural Research 34: 258-260.

29. Majer, P., L. Sass, T. Lelley, L. Cseuz, I. Vass, D. Dudits and J. Pauk. 2008. Testing drought tolerance of wheat by a complex stress diagnostic system installed in greenhouse. Acta Biologica Szegediensis 52: 97-100.

30. Mousavi, A., KH. Kalantari, R. Jafari, N. Hasibi and K. Mahdavian. 2009. Study of the effects of $24-$ epibrassinolide and water stress on some physiological parameters in canola (Brassica napus L.) seedlings. Iranian Journal of Biology 23 (2) 275 -286. (In Farsi).

31. Nikzad, A. R., M. Dastfall and S. Sarikhani. 2013. Lines and cultivars of bread and durum wheat, barley and triticale suitable for sowing in Fars province. Research Bulletin. Fars Jehad e Keshavarzi Organization. Fars.

32. Oosterhuis, D. M. and P. M. Cartwirght. 1983. Spike differentiation and floret survival in semidwarf spring wheat as affected by water stress and photoperiod. Crop Science 23: 711-717.

33. Pessarakli, M. 2001. Handbook of Plant and Crop Physiology. $2^{\text {nd }}$ Ed. Marcel Dekker, Inc. New York.

34. Pierre, C. S., J. Petersona, A. Rossa, J. Ohma, M. Verhoerena, M. Larsona and B. Hoefera. 2008. White wheat grain quality changes with genotype, nitrogen fertilization, and water stress. Agronomy Journal 100: 414-420

35. Piraste, A. H. and Y. Emam. 2011. Yield and yield component responses of bread and durum wheat to PGRs under drought stress conditions in field and greenhouse. Environmental Stresses in Crop Science 5(1): 1-17. (In Farsi)

36. Rajala, A. and P. P. Sainio. 2001. Plant growth regulator effects on spring cereal root and shoot growth. Agronomy Journal 93: 936-943.

37. Rajala, A. 2003. Plant growth regulators to manipulate cereal growth in Northern growing conditions. PhD. Thesis, University of Helsinki, Finland.

38. Shakirova, F. M., A. R. Sakhabutdinova, M. V. Bezrukova, R. A. Fathkutdinova and D. R. Fatkhutdinova. 2003. Changes in the hormonal status of wheat seedlings induced by salicylic acid and salinity. Plant Science 164, 317324.

39. Shekoofa, A. and Y. Emam. 2008. Effect of nitrogen fertilization and plant growth regulators (PGRs) on yield of wheat (Triticum aestivum L.) cv. Shiraz. Journal of Agricultural Science and Technology 10:101-108. 


\title{
Effect of Three Growth Regulators on Grain Yield of Wheat Cultivars under Different Moisture Regimes
}

\author{
M. E. Sedaghat ${ }^{1}$ and Y. Emam ${ }^{*}$
}

(Received: November 18-2015; Accepted: February 23-2016)

\begin{abstract}
Plant growth regulators (PGRs) are used to prevent reduction in wheat grain yield under limited moisture conditions. The effect of 3 PGRs including cycocel, salicylic acid and brassinoestroeid on yield and yield components of four wheat cultivars (Chamran, Shiroudi, Pishtaz and Sirvan) under well watered and water stress (withheld irrigation after flowering) was examined. The experiment was carried out as a factorial split plot in a completely randomized block design with three replicates at research farm of Sarvestan, Fars province in 2014-15 growing season. The results showed that drought stress reduced ear weight, grains per ear, grain weight per ear, thousand grain weight, harvest index, biological yield and grain yield, significantly. Albeit, the extent of the decrease varied, i.e. the smallest and greatest decreases were found in thousand grain weight $(7 \%)$ and number of grains per ear (13\%), respectively. Furthermore, application of PGRs especially cycocel, could increase ear weight, grains per spike, harvest index, thousand grain weight and consequently, grain yield. Among cultivars, Sirvan had the highest and Shiroudi had the lowest yield under both moisture regimes. According to our results although drought stress suppresses wheat yield and yield components, PGRs could be harnessed to compensate some parts of drought stress. Therefore, use of PGRs could be recommended to alleviate the drought stress effect on bread wheat.
\end{abstract}

Keywords: Cycocel, Salicylic acid, Brasinosteroeid, Harvest index, Biological yield

1, 2. PhD. Student and Professor, Respectively, Department of Agronomy and Plant Breeding, College of Agriculture, Shiraz University, Shiraz, Iran.

*. Corresponding Author, Email: yaemam@shirazu.ac.ir 